\title{
SISTEM INFORMASI MANAJEMEN
}

(resume materi sistem informasi manajemen)

\author{
Eva Rianti \\ Indofoodtri \\ 1611050025 \\ System Informasi \\ evariantiindo.1611050025@mail.darmaja
}

ya.ac.id

\begin{abstract}
Sistem informasi manajemen adalah sistem perencanaan bagian dari pengendalian internal suatu bisnis yang meliputi pemanfaatan manusia, dokumen, teknologi, dan prosedur oleh akuntansi manajemen untuk memecahkan masalah bisnis seperti biaya produk, layanan atau suatu strategi bisnis. Disni ada tugas seorang manajer yaitu mengelola sumber daya agar dapat digunakan secara efektif untuk mengontrol biaya, data dan mengelola sumber daya. Adapun tugas seorang direktur yaitu mengetahui sistem yang ada di manajer dari direktur dan memberi kebijakan dari direktur, seperti memberi persetujuan izin dari direktur.

Data dan informasi : Data yaitu produk dan jasa.

Ada 3 dari data yaitu : - informasi, - data, informatika

- Informasiyaituinterprestasidaridatayangdarimentahdijadikaninformasi,atausesuatuyang bisa disajikan adaobjek

- Informatika biasanya akan disebut dengan penerapan dan studi informasi yang hasilnyananti akan masuk kedalam informasi atau objek yang sudah jadi sepertibuku.

Bentuk sistem informasi yaitu:
\end{abstract}

1. Sistem informasimanajemen

2. Sistem informasieksekutif

3. Sistem informasiperkantoran

4. Sistem informasi pendukungkeputusan

5. Sistem informasi prosestransaksi

6. Sistem informasi pendukungpakar

Adapun perbedaan sistem informasi dan teknologi informasi

Sistem informasi adalah kombinasi antara sumberkerja yang dikumpulkan untuk mencapai tujuan dalam sebuah organisasi. Sedangkan teknologi informasi yaitu mencakup perangkat keras, perangkat lunak untuk melaksanakan sejumlah tugas pemrosesan data seperti mentransmisikan, menyimpan data, memanipulasi, menampilkan data sehingga dapat diteraokan dalam sebuah organisasi.

Kata kunci : system informasi manajemen 
Fakultas computer

Sistem Informasi Manajemen 